\title{
THE BIOLOGY OF FLOWERING AND STRUCTURE OF SELECTED ELEMENTS OF Cornus alba L. FLOWERS
}

\author{
Agata Konarska \\ Department of Botany, University of Life Sciences in Lublin, Akademicka 15, 20-950 Lublin, Poland \\ e.mail: agata.konarska@up.lublin.pl
}

Rceived: 7.03.2009

\begin{abstract}
The biology of flowering and the micromorphology of Cornus alba flowers were studied using light and scanning electron microscopy. The flowering of white dogwood in 2008 lasted 35 days, and the lifespan of a single flower was 3 days. The number of flowers per inflorescence was variable (on the average, it was 89). The largest group of insects visiting the flowers of C. alba comprised Hymenoptera (mainly bees and andrenids), then ants, dipterans and beetles. They foraged the dogwood flowers most intensively between 11.00 and 15.00. The inconspicuous four-petalled flowers of C. alba were characterised by the occurrence of T-shaped, two-armed non-glandular trichomes covering the receptacle as well as observed on the petals of the corolla, the style of the pistil and the anthers in a smaller number. The trichomes were covered by a thick cuticle with characteristic outgrowths. They contained a living protoplast, and plastids were observed in the cytoplasm of the trichome cells. In addition, anomocytic stomata were found in the epidermis of the receptacle and in the epidermis of the corolla petals. The stigma of the pistil and the adaxial epidermis of the petals were composed of very numerous conical papillae.
\end{abstract}

Key words: Cornus alba, biology of flowering, flowers microstructure, trichomes, papillae, stomata

\section{INTRODUCTION}

Cornus alba (Cornaceae) belongs to anthropophytic species brought to Poland from Asia. It is a shrub reaching about $3 \mathrm{~m}$ in height with characteristic, intensively red stems being its main ornamental feature. The inconspicuous crěme-coloured flowers of white dogwood are tetracyclic, bisexual and clustered in cymose corymbs. White fleshy fruits are approx. $8 \mathrm{~mm}$ in length and approx. $4 \mathrm{~mm}$ in diameter. Seeds contain up to $30 \%$ of oil, which is used in industry (Xiang and B oufford, 2005). In the conditions of Poland, C. alba blooms in May and June. This species prefers moist and marshy areas. It tolerates smoke and air pollution well, that is why it is recommended for plantings in industrial areas. The white dogwood is a shrub well domesticated in the conditions of Poland, and recently it has been considered to be running wild. It is a frost-resistant species ( $\mathrm{S} \mathrm{z}$ w e y k ow s$\mathrm{ka}$ and Szweykowski, 2003; Seneta and Dolatowski, 2004).

Entomophilous flowers of dogwood develop 4 stamens and produce small amounts of pollen. In addition, they are furnished with a persistent disk-shaped nectary borne on the top of the ovary of the inferior pistil, which is also associated with entomophily of these plants. There is little information on the foraging value of white dogwood for pollinating insects and the type of its pollinators. Only Howes (1979) mentions C. alba as a species providing nectar to bees in the conditions of Asia.

No data was found on the micromorphology of flowers and biology of flowering of white dogwood, either. Therefore, the aim of this study was to present some aspects of biology of flowering of $C$. alba, as well as to investigate the structure of selected elements of flowers using light and electron scanning microscopy.

\section{MATERIALS AND METHODS}

Observations related to the biology of flowering of Cornus alba shrubs were carried out in 2008 at the Botanical Garden of the Maria Curie-Skłodowska University in Lublin, Poland. The time and duration of flowering of the shrub, the number of flowers in 10 randomly selected inflorescences as well as the lifespan of a single flower, were all determined based on daily observations of the development of marked flower buds. At the full flowering of the shrub, the number and type of insects visiting white dogwood flowers were also observed for 3 successive days. The investigation of the structure of certain flower elements (the receptacle 
and trichomes covering its surface, petals of the corolla, the style and pollen grains) was made using light and electron scanning microscopy, by sampling flowers which had open petals of the corolla and closed anthers. The surface of the receptacle and of the style was observed with a BS-300 Tesla scanning microscope. In addition, semi-permanent slides were prepared in glycerol from fresh portions of particular elements of the flower. Pollen grains were stained with acetocarmine in order to determine their viability.

\section{RESULTS}

In the climatic conditions of Lublin, the flowering of Cornus alba in 2008 started on 27 April and it lasted until 31 May (35 days). However, single inflorescences at full bloom also appeared at the ends of the fresh shoots in October 2008. The lifespan of a single flower was 3 days. After the opening of the petals of the corolla, anther dehiscence was observed very quickly, already on the first day. On the third day, petal and stamen abscission occurred, which was accompanied by a change in the colour of the nectary from yellow to red. The number of flowers per inflorescence ranged between 48 and 167 (on the average 89). During the flowering of the shrubs, different groups of insects were observed on the C. alba flowers: Hymenoptera (mainly bees and andrenids), accounting for $39.6 \%$ of all insects recorded in the flowers, ants $(32.0 \%)$, dipterans $(12.3 \%)$ and beetles $(6.6 \%)$. Moreover, arachnids made up a rather large group of invertebrates observed on the inflorescences of dogwood (9.4\%). The insects visiting the dogwood flowers were interested in their pollen and nectar. They foraged the dogwood flowers from early morning hours (from 7.00) until late afternoon (17.00), most intensively between 11.00 and 15.00 .

The fine $C$. alba flowers, $8-10 \mathrm{~mm}$ in diameter, had an inconspicuous calyx composed of 4 sepals, 1.0$2.0 \mathrm{~mm}$ long, and 4 crěme-white petals of the corolla with silky lustre, $4.0-4.5 \mathrm{~mm}$ long, as well as 4 stamens, alternating with the petals of the corolla, with bright yellow anthers and long stamen filaments (Fig. 1). The style of the inferior pistil was ca. $2.0-2.5 \mathrm{~mm}$ in length. Its base was surrounded by a quite large ringshaped nectary with an outer diameter of approx. 1.5 $\mathrm{mm}$ and a height of approx. $0.5 \mathrm{~mm}$ (Figs 1,2).

When viewed by SEM, the surface of the receptacle, fused with the ovary of the inferior pistil, was characterised by the occurrence of numerous two-armed non-glandular trichomes with an elongated fusiform shape, situated parallel to the receptacle surface (Figs 2, 3). In the middle of its length, that is, at the place where it was attached to the epidermis, the $\mathrm{T}$-shaped trichome had the largest diameter, whereas in the terminal directions its diameter decreased. The outer cell wall of the trichome was covered by a cuticle forming different-sized conical outgrowths arranged irregularly or sparsely, linearly (Figs 3, 4). When viewed by LM, the two-armed trichomes were characterised by a different thickness of the cell wall and by a living protoplast (Figs 5-7). The outer wall of the apical cell of the trichome was marked by the greatest thickness (Figs 6,7). The interior of the trichome was filled by a large vacuole with the peripherally located cytoplasm in which plastids occurred (Figs 6, 7). The length of the trichomes ranged between $200 \mu \mathrm{m}$ and $400 \mu \mathrm{m}$. The fusiform trichomes were attached to the epidermis of the receptacle through the basal cell, situated between the epidermal cells (Fig. 7).

When viewed by SEM, the epidermal cells of the receptacle had slightly protruding outer walls covered by a striated cuticle with the striae running in different directions (Figs 8, 10). Anomocytic stomata, raised above the surface of the epidermis and generally surrounded by six epidermal cells, were observed rarely (Figs 8, 9).

When viewed by SEM, the style of the pistil was covered with differently arranged epidermal cells, at places forming regular rows, covered by a strongly striated cuticle, usually with the arrangement of the striae parallel to the long axis of the style or the radial arrangement around the stomata (Figs 11-13). In the epidermis of the style, open stomata occurred in quite great numbers (Figs 11-13), as well as few nonglandular trichomes, similar to those observed in the receptacle (Fig. 11). Inside the stomata pores, wax granules sometimes accumulated (Fig. 12). The sigma of the pistil was made up of very numerous cylindrical papillae with their arrangement resembling a "brush" (Fig. 11).

When viewed by light microscopy, the adaxial epidermis of the corolla petals was characterised by densely packed cells forming conical "teat"-shaped papillae approx. $50 \mu \mathrm{m}$ in height (Figs 14-15). Stomata were observed quite rarely (on the average, 18 stomata per $\mathrm{mm}^{2}$ ), with a length of the stomatal cells from 26.7 $\mu \mathrm{m}$ up to $39.2 \mu \mathrm{m}$ (on the average $34.5 \mu \mathrm{m}$ ), which were clustered mainly in the apical part of the petal and surrounded by $5-8$ epidermal cells. In the cells of the basal part of the petal, calcium oxalate crystals occurred in the form of quite large druses. In turn, the abaxial epidermis of the corolla petals was distinguished by the presence of more numerous stomata (on the average, 110 pores per $\mathrm{mm}^{2}$ of epidermis) than it was found on the upper surface of the petal, but with a smaller length of the stomatal cells (from $24.9 \mu \mathrm{m}$ to $39.2 \mu \mathrm{m}$, on the average $28.6 \mu \mathrm{m}$ ). The stomata were surrounded by 5-7 epidermal cells (Figs 16, 17). The epidermis was covered with trichomes similar to those 

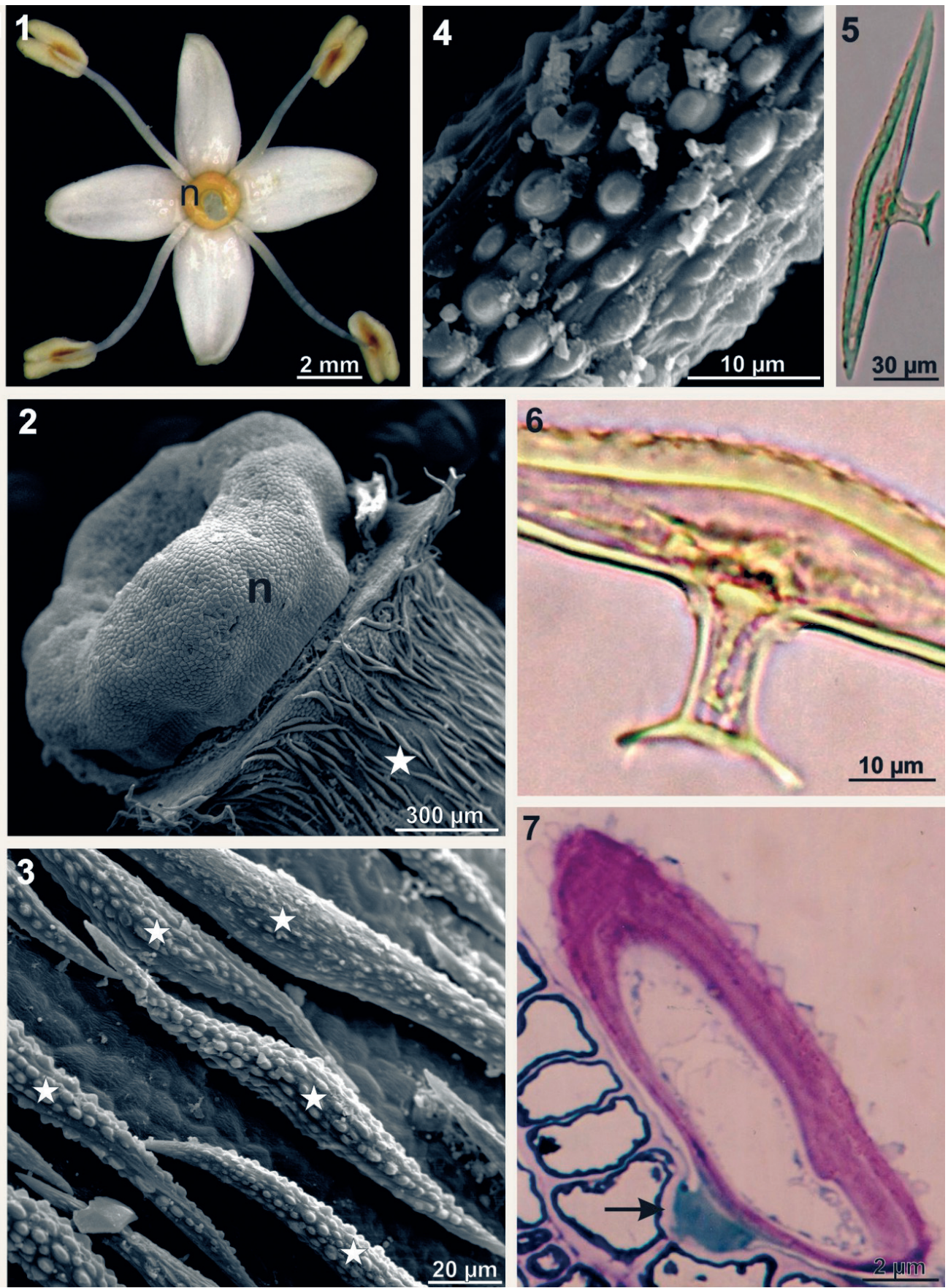

Plate 1. Fig. 1. Flower of Cornus alba with the nectary located around the style (n). Fig. 2. SEM. Fragment of Cornus alba flower with the nectary (n) and receptacle with trichomes (asterisk). Fig. 3. SEM. Non-glandular trichomes on the receptacle surface of the Cornus alba flower (asterisks). Fig. 4. Fragment of a non-glandular trichome. Figs 5-6. LM. Two-armed, T-shaped trichomes of the receptacle of the $C$. alba flower. Visible protoplast with plastids. Fig. 7. LM. Cross-section of the receptacle with a trichome of the $C$. alba flower. Note the protoplast and vacuole, arrow - the basal cell of the trichome. 

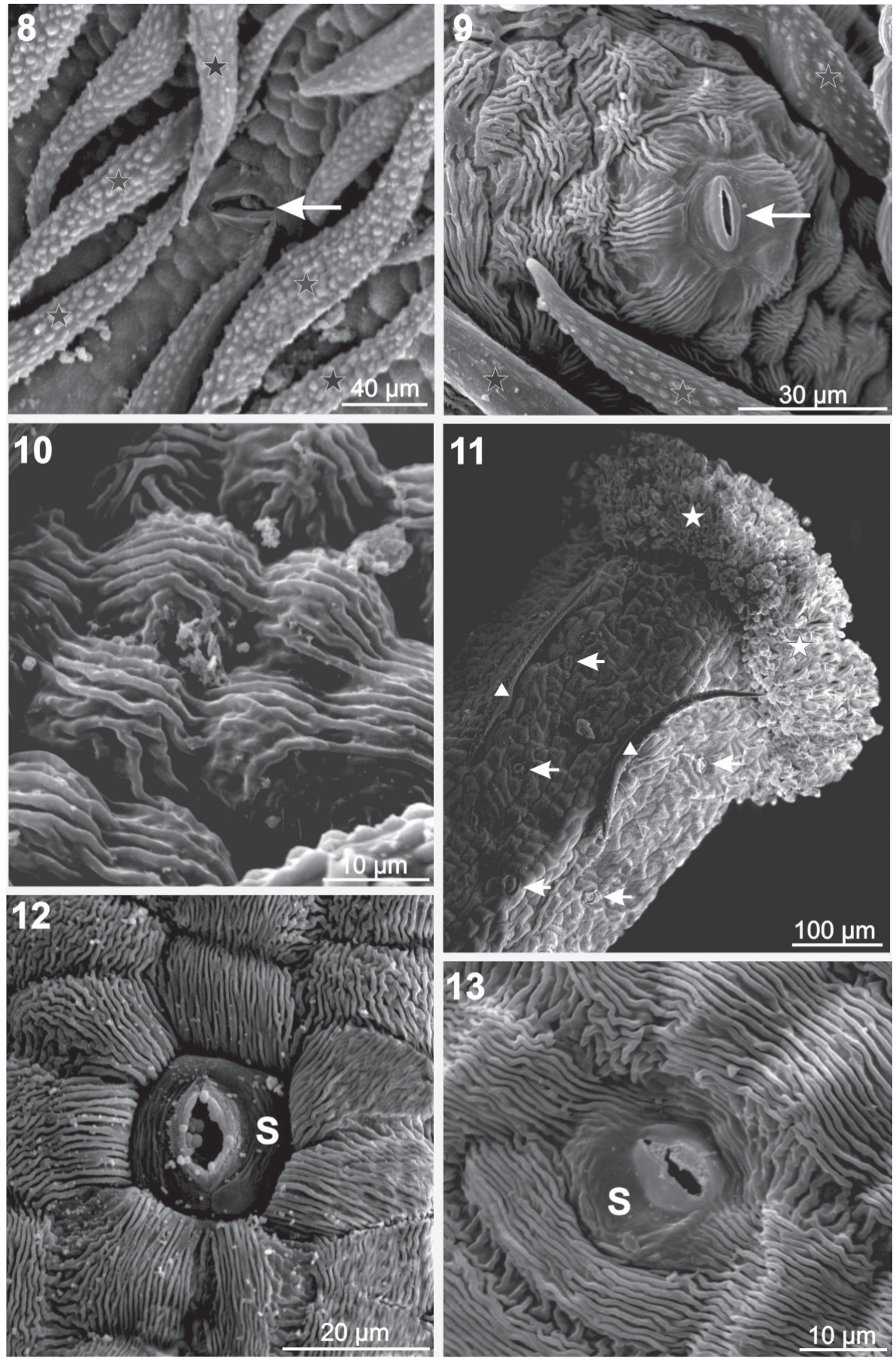

Plate 2. Fig. 8-10. Fragments of the striated epidermis of the receptacle of the $C$. alba flower with non-glandular trichomes (asterisks) and stomata (arrows). Fig. 11. Style of the C. alba flower with papillae on the stigma (asterisks), nonglandular trichomes (triangles) and stomata (arrows). Figs 12, 13. Stomata (S) of the C. alba flower's style surface; visible cuticular striae on the surface of epidermal cells. 

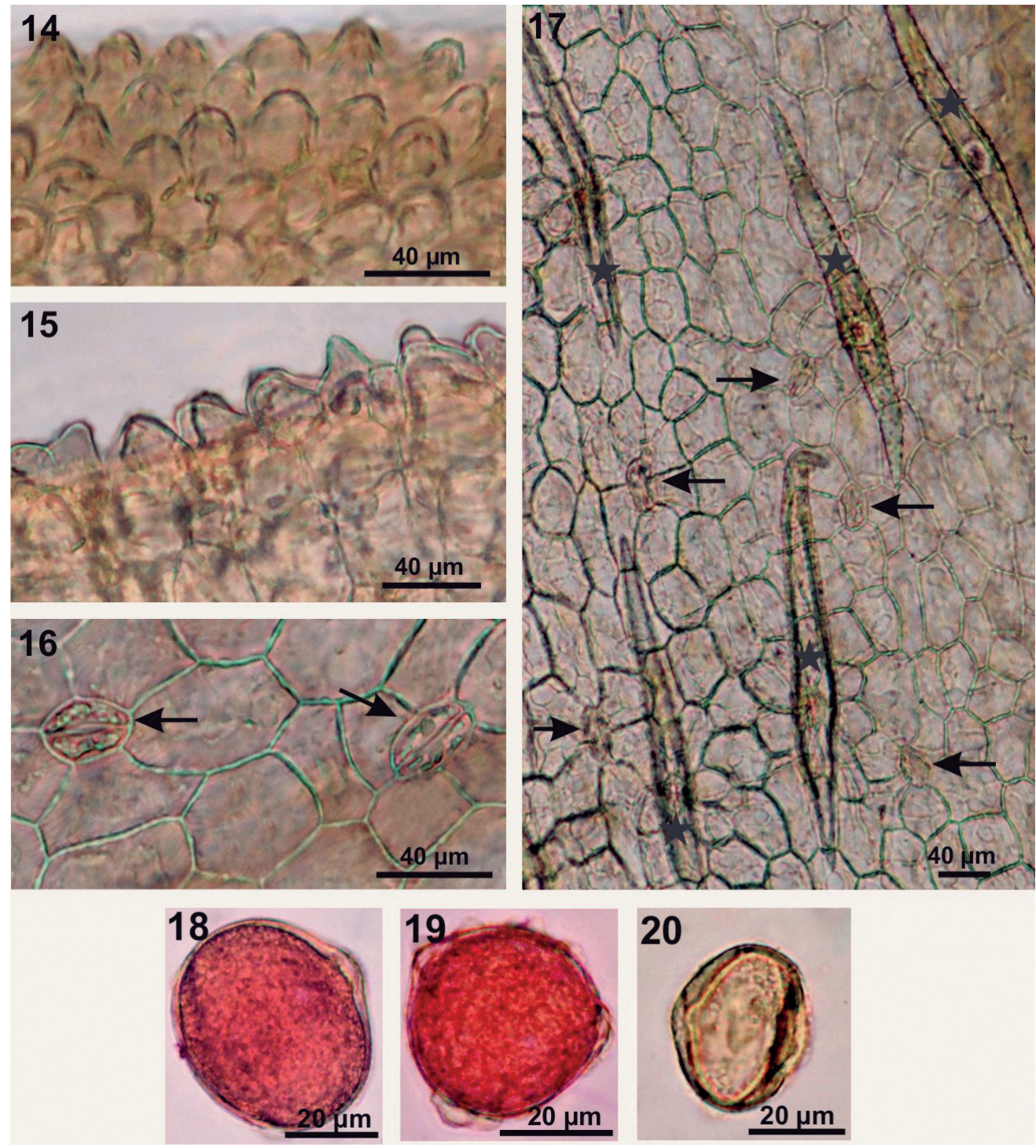

Plate 3. Figs 14, 15. Pappilae on the adaxial surface of the petal of the C. alba flower. Fig 16. Stomata (arrows) on the abaxial surface of the petal of the $C$. alba flower Fig. 17. Trichomes (asterisks) and stomata (arrows) on the abaxial surface of the petal of the C. alba flower. Figs 18-20. Pollen grains of C. alba. 18 - equatorial view, 19 - polar view. Note an uncoloured, misshapen grain (Fig. 20).

observed in the receptacle (Fig. 17). The two-armed trichomes were arranged regularly in the direction of the long axis of the petal. Their horizontal length was different, from $200 \mu \mathrm{m}$ up to over $400 \mu \mathrm{m}$. The diameter of the trichome in the middle of its length was 26.8 $\mu \mathrm{m}$, on the average. The cuticle covering the adaxial epidermis was marked by striation.

The stamen anthers, similarly to the corolla petals, receptacle and style, were furnished with not very numerous two-armed trichomes (not shown).

Pollen grains of white dogwood belong to the tricolporate type (Figs 18-20). The length of the equatorial axis (E) ranged from $35.6 \mu \mathrm{m}$ to $57.0 \mu \mathrm{m}$ (on the average, it was $43.8 \mu \mathrm{m}$ ), whereas polar axis length (P) ranged between $40.1 \mu \mathrm{m}$ and $73.0 \mu \mathrm{m}$ (on the average $49.6 \mu \mathrm{m}$ ). According to Erdtman's scale (1952), based on the P/E ratio $=1.13$, it was found that dogwood grains were slightly elongated (prolatospheroides type). The exine was predominantly 1.8 $\mu \mathrm{m}$ thick and its thickness increased in the colpus region, in the equatorial axis area (Figs 18-20). The viability of pollen grains was $92.5 \%$. Among non-viable pollen (no staining with acetocarmine), deformed, not fully developed grains were also observed (Fig. 20). 


\section{DISSCUSION}

The four-petalled flowers of Cornus alba, clustered in corymbs, do not differ in their structure and appearance from the flowers of several other known species such as: red osier dogwood (C. stolonifera) and common dogwood (C. sanguinea) (R e i c h h olf and Steinbach, 1995; Seneta and Dolatowski, 2004), as well as giant dogwood (C. controversa) and alternate-leaf dogwood ( $C$. alternifolia) (B u g a ł a, 2000). The flowers of European cornel (C. mas) also have a similar structure to the flowers of $C$. alba, however, their inflorescences are subtended by four bracts (Podbielkowski, 1989; Mynett and To m ż y ń s k a , 1999).

The characteristic non-glandular trichomes, observed in great numbers on the surface of the receptacle of $C$. alba, on the style of the pistil and the bottom side of the corolla petals, can limit insect feeding, both ants and aphid larvae, hindering their movement on the surface of the organ, thereby inhibiting access to the delicate generative parts, as well as they can reduce the level of pollen or nectar robbery. A g r a w a l (2001) and A ndres and Connor (2003) report a similar effect of trichomes present on different organs of other plant species. In addition, living trichomes of $C$. alba could produce special secretions irritating the digestive system of pests. Such an additional function of nonglandular trichomes has been described by $\mathrm{He}$ a l y et al. (2005) and Guzicka and Woźn y (2006). The covering of the receptacle and of the bottom side of the corolla petals with trichomes has also been described by Reichholf and Steinbach (1995) and S e net a and D ol a tow s ki (2004) in Cornus sanguinea. The two-armed, T-shaped trichomes of similar type have also been observed in other plant species from different botanical families (Convolvulaceae, Lobeliaceae) (A n e li, 1976; E v e r t, 2006). In turn, the T-shaped non-glandular trichomes, with a two-armed apical cell, but with a three-celled base, have also been observed in representatives of Asteraceae (B roda, 1986; Głowniak, 1999; P op a and $\mathrm{S}$ i p o s , 2009).

The papillae, occurring on the upper surface of the petals of the corolla, gave silky lustre to the elements of the perianth, which also had an impact on the effects of illumination of the flower interior. Such a feature of the corolla petals may signal to a particular group of insects the presence of food and have a luring effect on them. B a n a s z a (1987) reports such adaptation of plants to insect pollination. Scent, colour of flowers as well as other indicators and colour signals are included by this author in the so-called signal attractants, as opposed to pollen and nectar considered to be food attractants.
The insects visiting the flowers of $C$. alba showed interest both in pollen and nectar. It seems, however, that flowers of this species secret nectar not very abundantly, since we were not able to collect, using the pipette method, a sufficient amount of it in order to determine nectar production and the percentage sugar content in the nectar.

At the full flowering of the shrub, the main insects observed on the flowers of white dogwood were Hymenoptera, both bees and andrenids. No information was found in literature data on the pollinators of $C$. alba. But results relating to other Cornus species were gathered. According to Hobbs and Lilly (1954), the main pollinators of $C$. canadensis are bees collecting pollen from flowers of this species, whereas bees and bumblebees are the insects which visit the flowers of $C$. florida, $C$. sericea and $C$. mas ( $\mathrm{G} \mathrm{u} \mathrm{n} \mathrm{a-}$ t ille ke and Gun at i lle ke, 1984). In turn, Mayor et al. (1999) think that Halictidae, Andrenidae and Hymenoptera make up the largest group of pollinators of C. florida flowers. The pollinators of C. sanguinea are Hymenoptera in $67.4 \%$ and Diptera in $22.6 \%$ (Mayor et al. 1999). These values are variable and dependent, inter alia, on the population and flowering stage (Guitian et al. 1996). According to K ołt o w s ki (2006), the flowers of Cornus mas are visited by bees in large numbers. In turn, it is $C$. mas which is indicated by Li p iń s ki (1976) and S z w e y k ow s k a and S z w e y k o w s ki (2003) as a plant providing nectar to pollinators. It seems that certain inconsistencies in the obtained data may result from different conditions of particular studies. The author of the present paper was not able to determine the role of ants occurring in quite large numbers on the flowers of white dogwood. They could partly contribute to the pollination of the flowers of this species. However, it is more probable that their presence was related to the easy capture of food in the disk-shaped dogwood flowers or to the occurrence of aphids on the shrub.

In 2008 weather conditions during the flowering of white dogwood were changeable and they did not favour intensive foraging of insects. Storms or continuous rainfall happened frequently; they accelerated the cessation of flowering, thereby contributing to quicker stamen and petal abscission, and impeded foraging for insects. Probably that is why the effectiveness of pollination of flowers was reduced and there was a low percentage of fruits set (results unpublished).

\section{REFERENCES}

Andres M. R., Connor E. F., 2003. The communitywide and guild-specific effects of pubescence on the folivorous insects of manzanitas Arctostaphylos spp. Ecol. Entomol. 28: 283-396. 
Aneli N. A., 1975. Atlas epidermy lista. Mecniereba, Tbilisi.

B roda B., 1986. Zarys botaniki farmaceutycznej. Podręcznik dla studentów farmacji. PZWL.

Bugała W., Drzewa i krzewy. Państwowe Wydawnictwo Rolnicze i Leśne, Warszawa.

Erdt m an G., 1952. Pollen morphology and plant taxonomy. Angiosperms. Almqvist and Wiksell, Stockholm.

Evert R. F., 2006. Esau`s plant anatomy: meristems, cells and tissues of the plant body: their structure, function, and development. Wiley and Sons (eds.), Inc., Hoboken, New Jersey.

Fordyce J. A., Agrawal A. A., 2001. The role of plant trichomes and Caterpillar group size on growth and defense of the pipevine swallowtail Battus philenor. J. Animal Ecol. 70: 997-1005.

Głowniak K., 1999. Diagnostyka morfologiczno-anatomiczna wybranych roślinnych surowców leczniczych. / Morphological and anatomical diagnostics of certain medicinal plant raw materials. Wyd. Katedry i Zakładu Farmakognozji AM w Lublinie, Lublin.

Guitian J., Guitian P., Navarro I., 1996. Spatiotemporal variation in the interaction between Cornus sanguine $a$ and its pollinatiors. Acta Oecol. 17 (4): 285-295.

Gunatilleke C. V. S., Gunatilleke I.A.U.N., 1984. Some observations on the reproductive biology of three species of Cornus (Cornaceae). J. Arnold Arbot. 65: 419-427.

Guzicka M., Woźny A., 2006. Typy komórek. [In:] Biologia komórki roślinnej. Struktura. Wojtaszek P., Woźny A., Ratajczak L. (eds.). Państwowe Wydawnictwo Naukowe, Warszawa.

Healy H., Horner H., Bailey T., Palmer R., 2005. A microscopic study of trichomes on gynoecia of normal and tetraploid clark cultivars of glycine max, and seven near isogenic lines. Int. J. Plant Sci. 166: 415-425.

Hobbs G. A., Lilly C. E., 1954. Ecology of species of Megachile latreille in the mixed Prairie region of southern Alerta with special reference to pollination of alfalfa. Ecology, 35 (4): 453-462.

Howes F. N., 1979. Plants and Beekeeping. Faber and Faber (eds). London; Boston.

Kołtowski Z., 2006. Wielki atlas roślin miododajnych. Przedsiębiorstwo Wydawnicze Rzeczpospolita S.A.

Lipiński M., 1976. Pożytki pszczele. Zapylanie i miododajność roślin. Państwowe Wydawnictwo Rolnicze i Leśne, Warszawa.

Mayor A. J., Grant J. F., Windham M.T., Trigiano R. N., 1999. Insect visitors to flowers of flowering dogwood, Cornus florida L. in eastern Tennessee: Potential pollinators. J. Arbor. 26 (4): 206-212.
Mynett M., Tomżyńska M., 1999. Drzewa i krzewy ozdobne. Oficyna Wydawnicza MULTICO, Warszawa.

Podbielkowski Z., 1989. Słownik roślin użytkowych. PWRiL, Warszawa.

Popa F., Sipos M., 2009. Epidermal formation - trichomes. Biharean Biologist, 3 (1): 27-32.

Reichholf J. H., Steinbach G., 1995. The Great Encyclopedia. Trees and shrubs. Muza SA, Warszawa.

Senet a W., Dolatowski J., 2004. Dendrologia. Państwowe Wydawnictwo Naukowe, Warszawa.

Szweykowska A., Szweykowski J., (red). 2003. Słownik botaniczny. Wiedza Powszechna, Warszawa.

Xiang J., Boufford D. E., 2005. Cornaceae. Flora of China, 14: 206-221.

\section{Biologia kwitnienia i struktura wybranych elementów kwiatów Cornus alba L.}

\section{Streszczenie}

Badano biologię kwitnienia oraz mikromorfologię kwiatów Cornus alba przy zastosowaniu mikroskopii świetlnej oraz skaningowej elektronowej. Kwitnienie derenia białego w roku 2008 trwało 35 dni, a długość życia pojedynczego kwiatu wyniosła 3 dni. Liczba kwiatów w kwiatostanie była zmienna (średnio wynosiła 89). Najliczniejszą grupą owadów odwiedzających kwiaty $C$. alba były błonkówki (pszczoły i pszczolinki), następnie mrówki, muchówki i chrząszcze. Oblatywały one kwiaty derenia najintensywniej między godzinami 10.00 a 15.00 . Niepozorne, czterokrotne kwiaty $C$. alba charakteryzowały się występowaniem T-kształtnych, dwuramiennych, mechanicznych włosków pokrywających dno kwiatowe, a także w mniejszej liczbie obserwowanych na płatkach korony, szyjce słupka oraz pylnikach. Włoski pokryte były grubą kutykulą z charakterystycznymi wyrostkami. Zawierały żywy protoplast, a w cytoplazmie komórek włosków obserwowano plastydy. W epidermie dna kwiatowego i abaksialnej epidermie płatków korony występowały ponadto anomocytyczne aparaty szparkowe. Znamię słupka, jak i adaksialną epidermę płatków korony budowały bardzo liczne stożkowate brodawki (papille). 